IZA DP No. 6260

Pitfalls of Immigrant Inclusion into the European Welfare State

Martin Kahanec

Anna M.-H. Kim

Klaus F. Zimmermann

December 2011 


\title{
Pitfalls of Immigrant Inclusion into the European Welfare State
}

\author{
Martin Kahanec \\ Central European University \\ and IZA \\ Anna M.-H. Kim \\ $I Z A$ \\ Klaus F. Zimmermann \\ IZA and Bonn University
}
Discussion Paper No. 6260
December 2011

\author{
IZA \\ P.O. Box 7240 \\ 53072 Bonn \\ Germany \\ Phone: +49-228-3894-0 \\ Fax: +49-228-3894-180 \\ E-mail: iza@iza.org
}

\begin{abstract}
Any opinions expressed here are those of the author(s) and not those of IZA. Research published in this series may include views on policy, but the institute itself takes no institutional policy positions.

The Institute for the Study of Labor (IZA) in Bonn is a local and virtual international research center and a place of communication between science, politics and business. IZA is an independent nonprofit organization supported by Deutsche Post Foundation. The center is associated with the University of Bonn and offers a stimulating research environment through its international network, workshops and conferences, data service, project support, research visits and doctoral program. IZA engages in (i) original and internationally competitive research in all fields of labor economics, (ii) development of policy concepts, and (iii) dissemination of research results and concepts to the interested public.
\end{abstract}

IZA Discussion Papers often represent preliminary work and are circulated to encourage discussion. Citation of such a paper should account for its provisional character. A revised version may be available directly from the author. 


\section{ABSTRACT}

\section{Pitfalls of Immigrant Inclusion into the European Welfare State}

This paper's main purpose is to gauge immigrants' demand for social assistance and services and identify the key barriers to social and labor market inclusion of immigrants in the European Union. The data from an online primary survey of experts from organizations working on immigrant integration in the EU is analyzed using simple comparative statistical methods; the robustness of the results is tested by means of Logit and ordered Logit statistical models. We find that the general public in Europe has rather negative attitudes towards immigrants. Although the business community views immigrants somewhat less negatively, barriers to immigrant labor market inclusion identified include language and human capital gaps, a lack of recognition of foreign qualifications, discrimination, intransparent labor markets and institutional barriers such as legal restrictions for foreign citizens. Exclusion from higher education, housing and the services of the financial sector aggravate these barriers. Changes in the areas of salaried employment, education, social insurance, mobility and attitudes are seen as most desired by members of ethnic minorities. The current economic downturn is believed to have increased the importance of active inclusion policies, especially in the areas of employment and education. These results appear to be robust with respect to a number of characteristics of respondents and their organizations.

JEL Classification: J15, J71, J78

Keywords: ethnic minorities, migration, labor market integration, economic crisis, enlarged European Union, welfare state

Corresponding author:

Klaus F. Zimmermann

IZA

P.O. Box 7240

53072 Bonn

Germany

E-mail: Zimmermann@iza.org 


\section{Introduction}

The concept of immigrants taking advantage of the host state's welfare benefits and choosing host countries that offer generous welfare pervades much of the migration policy debate. Indeed, Borjas (1999) coins the term "magnet effect" of welfare generosity on the migration decision. In the EU, a massive growth of migration both within and from outside the EU in recent decades, and in particular following the 2004 and 2007 EU enlargements, has increasingly drawn the attention of both policy makers and researchers to immigrants' use of the welfare system. The focus has been on the disparities prevailing in the labor market participation and use of social services between native and immigrant populations.

It is widely regarded that failing labor market integration perpetuates the social exclusion of immigrants and vice versa. ${ }^{1}$ Understanding this vicious circle requires a more critical insight and investigation into the factors that hinder the social and labor market integration of immigrants. Central to this investigation is the role of social assistance and services. While improperly designed welfare instruments may lead to adverse social and labor market outcomes, they may also help immigrants to participate more easily and better in the social and economic life of their host society. ${ }^{2}$

This issue has been particularly tricky to tackle in the EU, since most of the Member States - unlike the traditional immigration countries like Canada and the US - have relied on a temporary-based migration system rather than a permanent one. The nonpermanent migration system of the EU attracted a predominantly low-educated and

\footnotetext{
${ }^{1}$ See Kahanec and Zimmermann (2011) and Zimmermann, Kahanec, Constant, DeVoretz, Gataullina and Zaiceva (2008) for a comprehensive account.

${ }^{2}$ See Fix, Capps, and Kaushal (2009); Zimmermann, Kahanec, Barrett, Giulietti, Maître and Guzi (2011).
} 
low-skilled foreign workforce in the past, leading to both economic and social marginalization of ethnic minority populations in many receiving countries. ${ }^{3}$

Indeed, Barrett and Maître (2011) show that it is rather the adverse compositional effect that drives immigrants into welfare take up rather than any residual immigrantspecific factor. Moreover, studying the role of unemployment benefits, Giulietti, Guzi, Kahanec and Zimmermann (2011) find no evidence for the belief that migrants choose countries that offer more generous welfare. These findings suggest that the policy debate about migration is wrongly pitched: it is rather immigrants' limited access to - rather than abuse of or attraction to welfare - that is the key problem. In fact, immigrants may often take up less welfare measures than comparable natives even if they are eligible, since they are not well-enough informed or may want to avoid the stigma. In addition, not accepting help could further obstruct the integration process in the long run. It follows that a critical scrutiny of the barriers immigrants face when accessing social assistance and services is required.

This paper's main purpose is to gauge immigrants' demand for social assistance and services and identify the key barriers to social and labor market inclusion of immigrants in the EU, with the help of a unique dataset from the purpose-made IZA Expert Opinion Survey. The survey's two waves, in 2007 and 2010, provide an extended account of stakeholders' view on immigrant exclusion in the 27 Member States as well as expert opinions on the barriers immigrants face and the needs vis-àvis their current social and labor market status in the host countries. We comparatively evaluate the evidence, test the stability of our findings and draw policy conclusions.

\footnotetext{
${ }^{3} \operatorname{OECD}(2008,2009)$.
} 


\section{Background literature}

The decision to migrate may involve a migrant's concern for his or her expected income, which includes unemployment benefit when inactive (Heitmueller, 2005). ${ }^{4}$ Earlier studies on the US find that immigrant households experience more and longer welfare spells and consequently spend a longer time participating in welfare programs (Borjas and Hilton, 1996). This has been denoted as the "magnet effect hypothesis", which argues that welfare generous states tend to attract migrants and encourage their dependency on welfare. This negative acculturation ties into larger concerns about the moral hazards of welfare expressed by many of those in favor of the broader goals of welfare reform (Fix, Capps and Kaushal, 2009).

However, more recent studies have called for caution and argue that the validity of these studies is limited. Van Hook and Bean (2009), for example, assert that distinguishing between different welfare programs (cash vs. non-cash assistance, income supplement vs. income replacement) is critical to identify and generalize the negative effects of welfare benefits on immigration and immigrant economic integration. Kaestner and Kaushal (2005) argue that the migration decision is based on information about the availability of jobs rather than the availability of welfare benefits.

For the European Union Barrett and Maitre (2011) show that only for some types of social benefits and only in some countries are immigrant welfare take-up rates higher compared to natives. Moreover, when they account for immigrant-native differences

\footnotetext{
${ }^{4}$ See Mayda (2010) for a comprehensive empirical study of push and pull factors of the migration decision.
} 
in characteristics and eligibility, the general pattern they find is that in most cases immigrants actually exhibit lower- and not higher- welfare use.

When comparing experiences of the major receiving economies of the EU many studies have found that immigrant selection policy and divergent characteristics of immigrants lead to different outcomes (e.g. Barrett and McCarthy, 2008; Drinkwater, Eade and Garapich, 2009). The study by Riphahn (2004) on German guest workers, for example, suggests that the state's early immigration policy, which primarily attracted low-skilled workers, is essentially linked to higher use of welfare benefits by immigrants than natives. In that context immigration policy plays a key role in determining both the propensity and the extent of the welfare needs of immigrants. The statistical evidence in most of the available studies remains weak or suggests only a marginal significance for the magnet effect of welfare generosity on an inflow of welfare-prone immigrants (see Barrett and McCarthy, 2008). Hansen and Lofstrom (2009) find that differences in welfare participation between natives and non-refugee migrants in Sweden are largely due to permanent unobserved characteristics, whereas the disproportionally high welfare participation rates among refugee migrants may be due to the existence of a "welfare trap".

Indeed, using macro-level data on 19 European countries, Giullietti, Guzi, Kahanec and Zimmerman (2011) show that the correlation of welfare generosity and immigration cannot be explained by a causal effect of welfare generosity on immigration, but rather, the tentative evidence they present suggests that immigration may increase welfare spending. 
We interpret the empirical evidence presented above to suggest that the higher immigrant welfare take up observed among immigrants is not driven by some residual propensity of immigrants to use welfare, for example due to immigrant selection driven by the welfare magnet argument. Rather, it appears to be an artifact of observable, and unfavorable, immigrant characteristics. If immigrants are compared to natives with comparable characteristics, lower immigrant welfare take up is observed than would be expected. Therefore, a socio-institutionally induced exclusion of the minority population from the host society and the labor market, and barriers to welfare assistance and services in particular, appears to be influential in shaping the patterns of immigrants' welfare needs and use.

In this vein, Constant, Kahanec and Zimmermann (2008), in their earlier study using the 2007 wave of the IZA Expert Opinion Survey, find that negative attitudes are the key barrier to immigrants' social and labor market integration. Our main contribution to this literature is that, besides barriers to immigrants' social and labor market inclusion, we also specifically identify barriers to their use of welfare assistance and services and evaluate the stability of these findings on the backdrop of the current financial and economic turmoil and also with respect to the respondents' characteristics.

\section{Data and methods: The IZA Expert Opinion Survey 2010}

In this section we illustrate how our key data source - the IZA Expert Opinion Survey

- reflects the conceptual issues needed to answer key questions on immigrant inclusion and the welfare state. The two waves of the IZA Expert Opinion Survey were conducted between May and July 2007 and between February and September 
2010. The 2010 questionnaire comprised of 12 main questions and 120 sub-questions and was conducted online for $27 \mathrm{EU}$ Member States in the respective official languages, with an additional option of English. It reflects the views of 156 experts from governmental and non-governmental organizations (NGOs) working on immigrant integration and ethnic minority rights across the Member States. The 2007 wave contains the views of 215 expert respondents. The first wave contains responses from all of the 27 EU Member States, whereas 26 Member States were represented in the second wave. ${ }^{5}$ The 2010 sample contains responses from employer associations ( 7 percent), employee associations or trade unions (14 percent), governmental organizations (8 percent), NGOs (52 percent), and other organizations (18 percent).The corresponding figures for 2007 are 10, 4, 9, 47, and 30 percent.

While the primary aim of the 2007 survey was to identify the barriers ethnic minority members face to labor market integration, the follow-up survey conducted in 2010 amid the financial crisis- goes beyond that. That survey tries to elicit the nature and degree of the problems experienced by the different immigrant groups in Europe's welfare states. The foreign-born minority groups in the survey include: EU, non-EU, all ethnic minorities and undocumented (illegal) immigrants. While we are aware that the evaluation of undocumented immigrants is inevitably limited because of their invisibility in formal institutions, we tried to include this group for as many questions as feasible, for example, in the questions about key labor-market and social exclusionrelated issues.

One of the key strengths of the extended IZA Expert Opinion Survey is that it captures changes in perceptions of welfare needs of the different immigrant minority

\footnotetext{
${ }^{5}$ There were no responses from Lithuania.
} 
populations from the pre-crisis period - 2007- to the crisis period - 2010. In doing so, we have added questions which investigate more details of institutional barriers and drawbacks in various policy areas which are considered most important. Moreover, in the 2010 wave we adopted a number of measures of social services and assistance and barriers to their use.

\section{Results}

The situation of immigrant integration in the EU remains grim. More than a half of total respondents (54 percent) in the survey said that ethnic minorities are at high or very high risk of being excluded from the labor market of the host economy, and 33 percent viewed this risk as medium. This appears to be a dominant and growing trend: compared to 32 percent in 2007, 45 percent of respondents in 2010 viewed labor market exclusion of ethnic minority populations in the EU as increasing rather than decreasing or constant.

According to experts' views negative perceptions about ethnic minorities prevail both among the general public and in the business world (see Figures 1 and 2). The general public is viewed to be more negative toward ethnic minority members than the business world. ${ }^{6}$ Society and business people both are reported to be more positive (and less negative) of EU immigrants.

[Figure 1 about here]

[Figure 2 about here]

\footnotetext{
${ }^{6}$ This may be due to many factors, including the perception of immigrants as more productive or cheaper employees, customers, or perhaps because the business world better understands social benefits or ignores social costs that immigration may bring about.
} 
Figure 3 illustrates experts' views on the barriers that different types of immigrant workforce face to participate in the labor market of their host economy. Language is one of the most common barriers reported for all groups of immigrants. Non-EU and undocumented immigrants especially, however, are believed to confront more institutional barriers when entering formal labor markets. Discrimination along with education and poor access to information are also seen as very important integration barriers for non-EU and undocumented immigrants.

[Figure 3 about here]

Limited recognition of immigrants' foreign qualifications in the receiving countries claimed by 40 percent of survey respondents for the category of non-EU and undocumented immigrants - is identified as a significant problem, possibly indicating educational marginalization of immigrants (see Figure 3). A similar response rate of "insufficient education" as a barrier may well be interwoven with a lack of skills or a failure of the host country recognizing qualifications received abroad. This further implies a risk of "brain waste", which is a loss of immigrant skills (Dustmann, Frattini and Preston, 2007; Shinnaoui and Narchal, 2010). Immigrant workers with their qualifications not recognized would simply be considered low-educated and end up doing low-skilled jobs in the host country.

Prejudice in the host society, or the natives' negative perceptions and attitudes towards immigrant minorities, appears to be the single most persistent and significant non-institutional barrier to labor market participation. In 2007 more than two thirds of total survey respondents (70 percent) considered discrimination the greatest barrier to 
labor market integration. In 2010 - a year of the Eurozone financial crisis - 63 percent of respondents reported that this was the case for non-EU as well as undocumented immigrants alike, whereas 24 percent believed this to be true of EU immigrants (see Figure 3).

Having identified the major barriers to labor market integration of immigrant minority populations, the survey explored the areas of policy where, in the view of the experts, immigrants' demand for change and improvement is growing. When asked about the minority population at greatest risk, more than three quarters (76\% in 2010 and $78 \%$ in 2007) of all respondents indicated that this minority demanded some changes concerning its social and labor market integration.

Figure 4 shows the areas where experts expressed the strongest demand for changes by the minority groups they believe are at the greatest risk of social exclusion. The perceived changes in priorities between 2007 and 2010 indicate that during a recession, people are more concerned about labor market integration than social wellbeing related areas such as housing, cultural and social activities, or, somewhat surprisingly, attitudes and acceptance by the natives.

Paid employment is the most prominent in the responses. Remarkably, according to the surveyed experts the demand for social insurance and other welfare benefits almost tripled in the crisis year compared to 2007. With regards to national and international mobility, 24 percent of respondents, a ten-fold increase since 2007, reported that immigrants and ethnic minorities demanded change. This increased demand for mobility may imply that migrant workers are in general more affected by 
the recession and are likely to seek easier mobility to move where they could have better earning opportunities. Additional areas where the focus has shifted include participation in trade unions and political life.

[Figure 4 about here]

We also consider experts' perceptions about the differences in the areas of change in 2010 by different groups of EU and non-EU immigrants. According to Figure 5, nonEU immigrants are viewed to desire changes in nearly all areas more frequently than EU immigrants, most notably in housing, health care and paid employment.

[Figure 5 about here]

Figure 6 supports the view of higher barriers of access to various services by non-EU immigrants compared to those coming from other EU countries. They are considerably more frequently seen as exposed to either a very high or a high risk of exclusion in all areas of public services. On the question about the degree of exclusion across various areas of services and by different groups of immigrants, a substantially higher proportion of respondents said that non-EU immigrants are excluded from the services of state employment agencies, either at the very high or high level (39 percent) or at least a medium level of risk (23 percent). Nearly half of total respondents said that non-EU immigrants experience discrimination by local public service officials, with 25 percent for very high risk, and 24 percent for high risk. The three areas where the share of respondents indicating a high or very high degree of exclusion for non-EU immigrants exceeds or equals 50 percent are higher education, housing and housing subsidies, and bank services and loans. 
[Figure 6 about here]

Illegal immigrants are seen as having even worse access to all kinds of public services than non-EU immigrants. For illegal immigrants the share of respondents reporting a high or very high degree of exclusion exceeds or equals 50 percent for all considered public services. This may be due to barriers such as legal or institutional constraints, discrimination, poor language and education, or lack of information.

The 2010 survey also asked the experts to evaluate the effect of the recession caused by the financial crisis on the role of active inclusion policies which are targeted at ethnic minority members. Over half of all respondents (53 percent) indicated that it was considerably or somewhat more important than before the crisis, and 30 percent said that it was just as important (see Figure 7). Thus, the overall importance of active inclusion polices and the enabling services to implement them is very high across Member States (see Figure 7).

[Figure 7 about here]

Figure 8 reveals which enabling services were seen as the most important in times of crises in 2010. Employment agency assistance and education were deemed equally most important, at 58 and 56 percent respectively. Demand for unemployment benefits is also high (40 percent), ranking only third among all the instruments, followed by language training at 33 .

[Figure 8 about here] 


\section{Explaining expert opinions}

The responses given by the experts give useful insights into the demand for, and barriers to, the social and labor market integration of immigrants. The message that unfolds in this analysis is that, according to the surveyed experts, the general public in Europe has a rather negative attitude towards immigrants, and this has become more marked throughout the crisis. ${ }^{7}$ Although the business world views immigrants somewhat less negatively, serious barriers to immigrants' labor market inclusion regarding language, discrimination, and human capital, exclusion from labor market information, and recognition of foreign qualification, as well as institutional barriers, are identified. Exclusion from higher education, housing and the services of the financial sector aggravate these barriers. Changes in the areas of paid employment, education, social insurance, mobility and attitudes are seen as desired by members of ethnic minorities. The economic downturn circa 2010 is viewed as increasing the importance of active inclusion policies especially in the areas of employment and education.

The external validity of these insights depends on their robustness with respect to various subjective factors. While we cannot exhaustively address the issue of the subjective nature of the expert opinions, we can test their stability with respect to some characteristics of the surveyed organizations and expert respondents.

Using the Logit and ordered Logit statistical models, we examine the effects of individual respondent's characteristics as well as the characteristics of the

\footnotetext{
${ }^{7}$ The results from Figure 4 indicate that significantly less respondents believe that immigrant and ethnic minorities require changes in the area of the attitudes of the majority population towards them. This may indicate a growing discouragement or fatigue of ethnic minorities in this area.
} 
organization he or she represents on the responses. Among individual characteristics we consider age, age squared and gender. Respondents' organizations are classified as employees' association (benchmark), employers' association, trade union, governmental organization primarily aimed at equal opportunities, other governmental organization, NGO primarily aimed at equal opportunities, NGO primarily aimed at labor market integration of ethnic minorities, NGO with primary objectives other than the labor market integration of ethnic minorities or equal opportunities, or other. In addition, we distinguish between organizations focusing on a specific ethnic minority (or ethnic minorities in general) as well as those primarily run by members of a specific ethnic minority (or ethnic minorities in general). Finally, we classify five regions of Europe to help account for regional variation of contextual variables: West (benchmark), including Austria, Belgium, France, Germany, Luxembourg and the Netherlands; the United Kingdom and Ireland; Scandinavia, including Denmark, Finland and Sweden; South, including Cyprus, Greece, Italy, Malta, Portugal and Spain; and East, including Bulgaria, the Czech Republic, Estonia, Hungary, Latvia, Poland, Romania, Slovakia and Slovenia.

We test the robustness of responses for the four most important barriers preventing ethnic minorities from fully participating in the labor market: institutional barriers, such as citizenship, or legal restrictions; insufficient knowledge of the official language(s); discriminatory attitudes and behavior towards ethnic minorities; and insufficient education. The generally insignificant results from the Logit model reported in Table 1, columns 1-4, demonstrate that whether or not any of these barriers is viewed as significant does not depend on (and, hence, is not biased by) individual characteristics of respondents or characteristics of the organization they 
represent. Except for ethnic focus and being run by ethnic minorities in column 1 we only find some regional effects to be statistically significant. In fact, the Wald test of the hypothesis that all the coefficients except the regional dummies are jointly equal to zero is rejected in all these models.

[Table 1 about here]

That neither individual nor organization's characteristics affect respondents' perceptions about whether any changes concerning social and labor market integration are demanded, and if so in which areas, is confirmed by the generally insignificant coefficients from the Logit model reported in columns 5 to 9. Besides one regional coefficient, the only significant coefficient is the positive effect of being a woman on experts' perception whether changes are required in the area of social insurance and benefits. Similarly, the ordered Logit model estimated to measure the effects of individual and organization's characteristics on respondent's perceptions about the barriers to integration (columns 10-14) shows that such effects are generally insignificant, with the exception of a few regional effects and the effects of age and gender in case of access to bank services. Again, the Wald test of the hypothesis that all the coefficients except the regional dummies are jointly equal to zero is rejected in all but one of these models (column 13).

We interpret this evidence to signify a reasonable degree of robustness of experts' perceptions with respect to their individual characteristics as well as the characteristics of the organizations they represent, and thus provide some support to the belief that the validity of our results is not limited to the available sample. 


\section{Policy discussion}

That ethnic and immigrant populations would like to change their situation legitimizes integration policy efforts. Facing difficulties with integration into both the labor market and social assistance and services puts immigrants into a very severe situation of double-marginalization. Tackling negative attitudes towards immigrants, which seem to constitute one of such barriers, is therefore in our view a most important objective of integration policies. Helping immigrants improve their language skills of the host country and removing administrative barriers that prevent them from fully participating in the labor market are other fruitful areas for policy efforts.

In contrast with the premise of excessive immigrant welfare take up so deeply entrenched in the European discourse, the literature suggests a different interpretation. Namely, if immigrants are found among welfare recipients more often than natives, it is rather due to adverse composition of immigrant populations than any peculiar immigrant-specific factor. Among comparable immigrants and natives, immigrants in fact exhibit lower welfare take up rates than natives (Zimmermann, Kahanec, Barrett, Giulietti, Maître and Guzi, 2011; Barrett and Maître, 2011). These findings hint at the existence of significant barriers to immigrants' access to welfare. They also highlight the importance of properly designed immigration policies, which largely determine the composition of immigrant populations.

Our IZA Expert Opinion Survey identifies and scales a number of barriers to inclusion as viewed by expert stakeholders. Based on our findings, some of the most urgent foci of policy efforts include access to housing and housing subsidies, higher education, 
family and child benefits, unemployment benefits, as well as employment agency assistance, including information about relevant job vacancies and training. Another important area where improvement is needed is the access to bank services and credit (loans, mortgages, consumer and business credit). This is even more important in the light of the increased significance of self-employment as means of earning one's living documented in the survey between 2007 and 2010. As non-EU and undocumented immigrants face the most severe risk of exclusion from social and economic opportunities, policy efforts should be targeted at these two groups. General policies should also aim at reducing the risk of being discriminated, neglected, uninformed, misinformed or otherwise mistreated by social service agencies. Such efforts need to be coordinated under an effective umbrella of antidiscrimination legislation.

It is crucial to understand that welfare inclusion policies should be viewed as means of broader social and labor market integration. Although they do not come at zero costs, they do serve as enabling services that have positive effects on the long-run stability of public finance. In effect, immigrant inclusion into welfare deserves special attention also in times of economic downturns and crises, when immigrants may be especially vulnerable.

\section{Conclusion}

A variety of barriers continue to hold back both economic and social integration of immigrant minorities in the EU. The findings of the IZA Expert Opinion Survey show that discriminatory attitudes of the natives remain a very powerful non-institutional 
barrier to the integration of ethnic minorities in the EU. Yet it is important to note that the labor market environment in the business world is slightly more favorable to people of ethnic minorities than the general public of the EU. This implies that there is an untested gap between the view of the public and the view of the business world. Although one reason for the differing perceptions of the general public about European immigrants and non-European ethnic minority immigrants would be the discrimination between "us" and "them", further study is required to identify the exact anatomy of various socially and institutionally constructed biases against people of ethnic minority origin across EU Member States. Knowing them will also allow us to identify variations in discriminatory behavior and target groups across countries as well as within. For example, the highly disadvantaged, and even stigmatized, position of Turks in Germany - rooted in the country's record of receiving low-educated and low-skilled guest workers from Turkey - is quite different in other Member States such as Sweden and the UK, which have different systems and histories of international migration.

The institutional barriers identified in the 2010 survey tell us that, in experts' view, ethnic minority immigrants' key concerns have shifted to the issues which are more directly related to their long-term economic well-being compared to the pre-crisis period. This is demonstrated in the change of the immigrant minorities' policy priorities between 2007 and 2010.

Education, including vocational and language training, remains a most important institutional issue together with citizenship and a lack of information about employment opportunities, which hamper labor market participation of all immigrants 
from non-EU backgrounds. Of particular importance is the 40 percent of respondents who reported that not recognizing the foreign qualifications of non-EU immigrants is a key barrier to labor market integration, compared to 20 percent for EU-migrants the "brain waste" phenomenon. Depreciation of immigrants' qualifications can, in the long run, have a significant detrimental impact both on the skill supply of the workforce and the welfare system of the EU's ageing economies.

Our survey has contributed to addressing a wide range of issues of barriers that different groups of immigrants have for integration into both the labor market and the welfare system of the host economy. We have also identified the key policy areas known as "enabling services" - which most matter to tackle the barriers prevailing at the EU level. Such efforts should include general antidiscrimination policies, but also efforts tackling specific integration barriers mentioned above.

Yet our study has limitations too. The findings of our survey do not fully reflect the problems which may be more specific and important at the national level other than at the EU level. This is attributed to the large geopolitical and socio-economic diversity of an enlarged EU. In sum, the underlying cross-country differences which are imbued in different immigration histories and systems of the 27 EU Member States should be taken into account in the general evaluation of the findings. This is also important for implementation of any new EU-level policy for "active inclusion" of the diverse immigrant minority populations in the Member States. 


\section{References}

Barrett, A. and Y. McCarthy (2008) "Immigrants and welfare programmes: Exploring the interactions between immigrant characteristics, immigrant welfare dependence, and welfare policy", Oxford Review of Economic Policy, 24 (3), 542-559.

Barrett, A. and B. Maître (2011), "Immigrant welfare receipt across Europe", IZA Discussion Paper No. 5515, Bonn: Institute for the Study of Labor, forthcoming in International Journal of Manpower.

Borjas, G.J. and L. Hilton (1996) "Immigration and the welfare state: Immigrant participation in means-tested entitlement programs", Quarterly Journal of Economics, $111(2), 575-604$.

Borjas, G.J. (1999) "Immigration and welfare magnets", Journal of Labor Economics, 17 (4), 607-637.

Constant, A., M. Kahanec and K.F. Zimmermann (2009) "Attitudes towards immigrants, other integration barriers, and their veracity", International Journal of Manpower, 30 (1-2), 5-14.

Drinkwater, S., J. Eade and M. Garapich (2009) "Poles apart? EU enlargement and the labour market outcomes of immigrants in the United Kingdom", International Migration, 47 (1), 161-190. 
Dustmann, C., T. Frattini and I. Preston (2007) A Study of the Migrant Workers and the National Minimum Wage and Enforcement Issues, University College London.

Fix, M.E., R. Capps and N. Kaushal. (2009) “Immigrants and Welfare: Overview,” in Immigrants and Welfare: The impact of welfare reform on America's newcomers, M.E. Fix (ed.), New York, Washington D.C.: Russell Sage Foundation.

Giulietti, C., M. Guzi, M. Kahanec and K.F. Zimmermann (2011) "Unemployment benefits and immigration: Evidence from the EU", IZA Discussion Paper No. 6075, Bonn: Institute for the Study of Labor, forthcoming in International Journal of Manpower.

Hansen, J. and M. Lofstrom (2008) “The dynamics of immigrant welfare and labor market behavior", Journal of Population Economics, 22(4), 941-970.

Heitmueller, A. (2005). 'Unemployment benefits, risk aversion, and migration incentives', Journal of Population Economics, 18(1), 93-112.

Kahanec, M. and K.F. Zimmermann (eds.) (2011) Ethnic Diversity in European Labor Markets: Challenges and solutions, Cheltenham: Edward Elgar.

Kaestner, R. and N. Kaushal (2005). "Immigrant and native responses to welfare reform", Journal of Population Economics, 18(1), 69-92. 
Mayda, A. (2010). "International migration: a panel data analysis of the determinants of bilateral flows", Journal of Population Economics, 23(4), 1249-1274.

OECD (2008) A Profile of Immigrant Populations in the 21st Century: Data from OECD countries, Paris: Organisation for Economic Co-operation and Development.

OECD (2009) International Migration Outlook 2009, Paris: Organisation for Economic Co-operation and Development.

Riphahn, R.T. (2004) "Immigration participation in social assistance programs", Applied Economics Quarterly, 50 (4), 329-362.

Shinnaoui, D. and R. Narchal (2010) "Brain gain to brain waste: Individual biases, prejudice, and discounting of migrant skills", Journal of International Migration and Integration, 11(4), 423-427.

Van Hook, J. and F.D. Bean (2009) "Immigrant welfare receipt: Implications for immigrant settlement and integration", in M.E. Fix. (ed.) Immigrants and Welfare: The impact of welfare reform on America's newcomers, New York, Washington D.C.: Russell Sage Foundation, pp. 93-122.

Zimmermann, K.F., M. Kahanec, A. Constant, D. DeVoretz, L. Gataullina and A. Zaiceva (2008) "Study on the social and labour market integration of ethnic minorities", IZA Research Report No.16, Bonn: Institute for the Study of Labor. 
Zimmermann, K.F., M. Kahanec, A. Barrett, C. Giulietti, B. Maître and M. Guzi (2011) "Study on active inclusion of immigrants", IZA Research Report, forthcoming. 
Figures and Tables

Figure 1 . The attitudes of the general public towards migrants

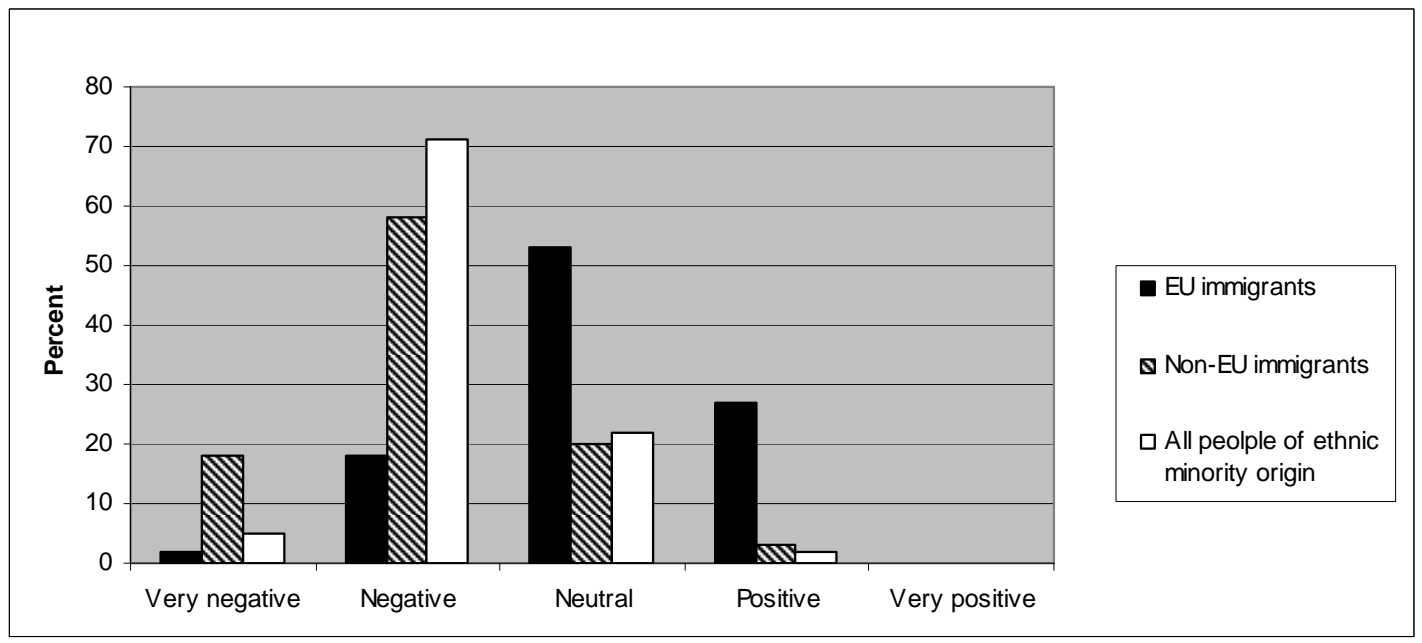

Source: IZA Expert Opinion Survey 2010.

Notes: Responses to the question: How would you describe the general public opinion and attitudes towards the following ethnic minorities?

Figure 2. The attitudes in the business world towards migrants

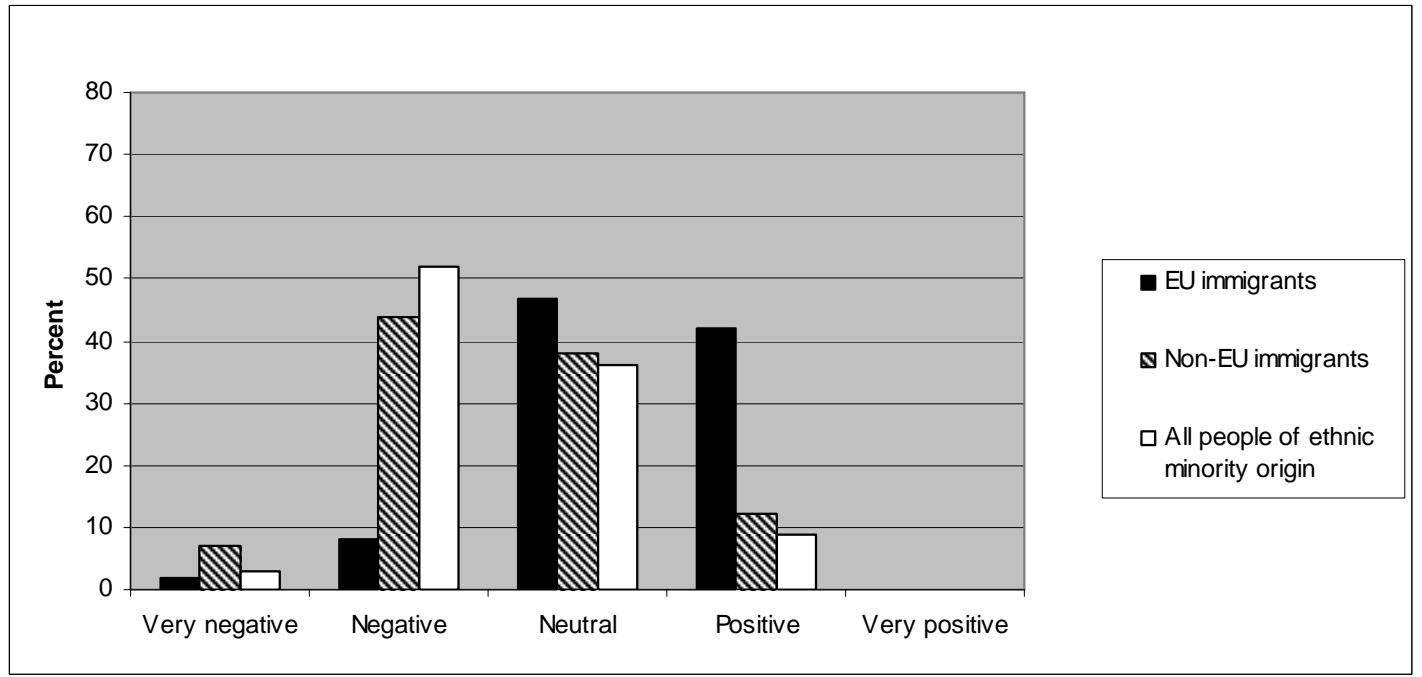

Source: IZA Expert Opinion Survey 2010.

Notes: Responses to the question: How would you describe the perception of the following ethnic minorities as employees and business partners in the business world, i.e. among managers, businessmen and businesswomen, and entrepreneurs? 
Figure 3. Barriers to labor market inclusion

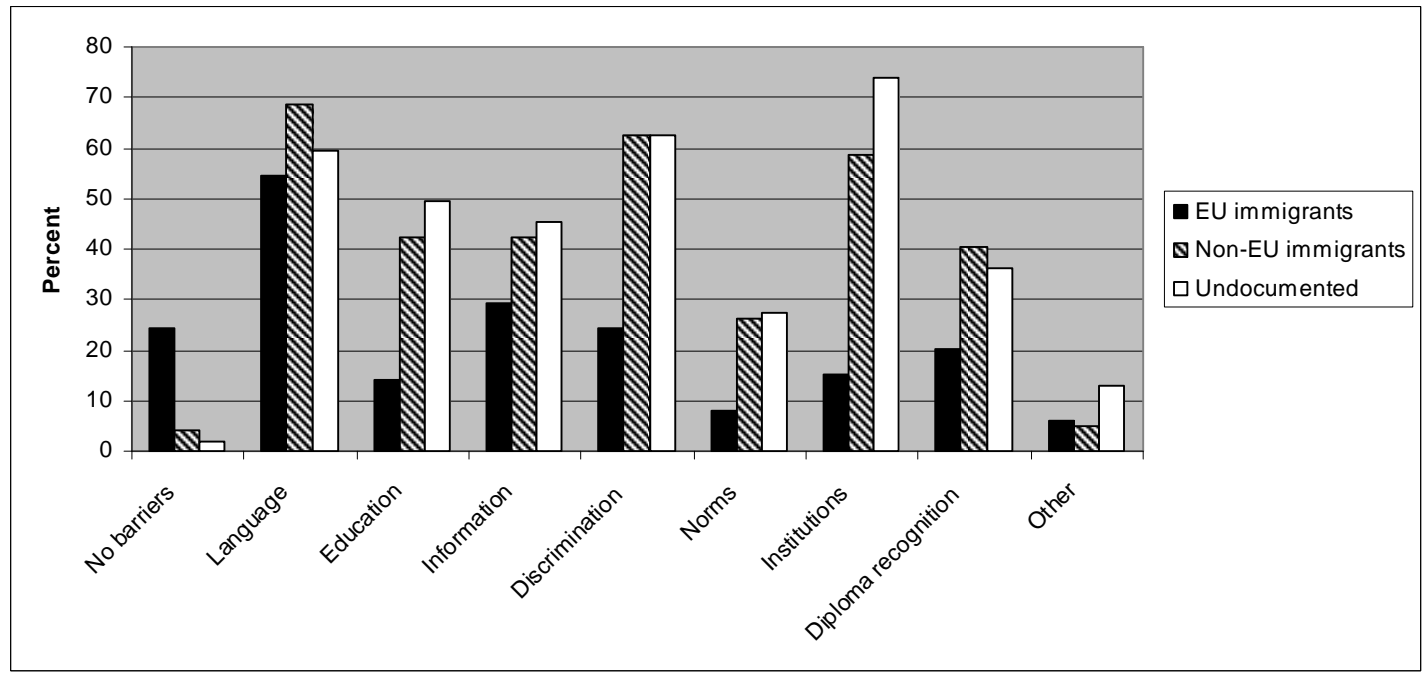

Source: IZA Expert Opinion Survey 2010

Notes: Responses to the question: What are the most significant barriers preventing ethnic minorities from fully participating in the labor market? [no barriers; insufficient knowledge of the official language(s); insufficient education; lack of information about employment opportunities; discriminatory attitudes and behavior towards ethnic minorities; social, cultural and religious norms originating from within these ethnic minorities; institutional barriers, such as citizenship, or legal restrictions; institutional barriers related to recognition of foreign qualifications; other, please specify]

Figure 4. Areas in which changes are required by year

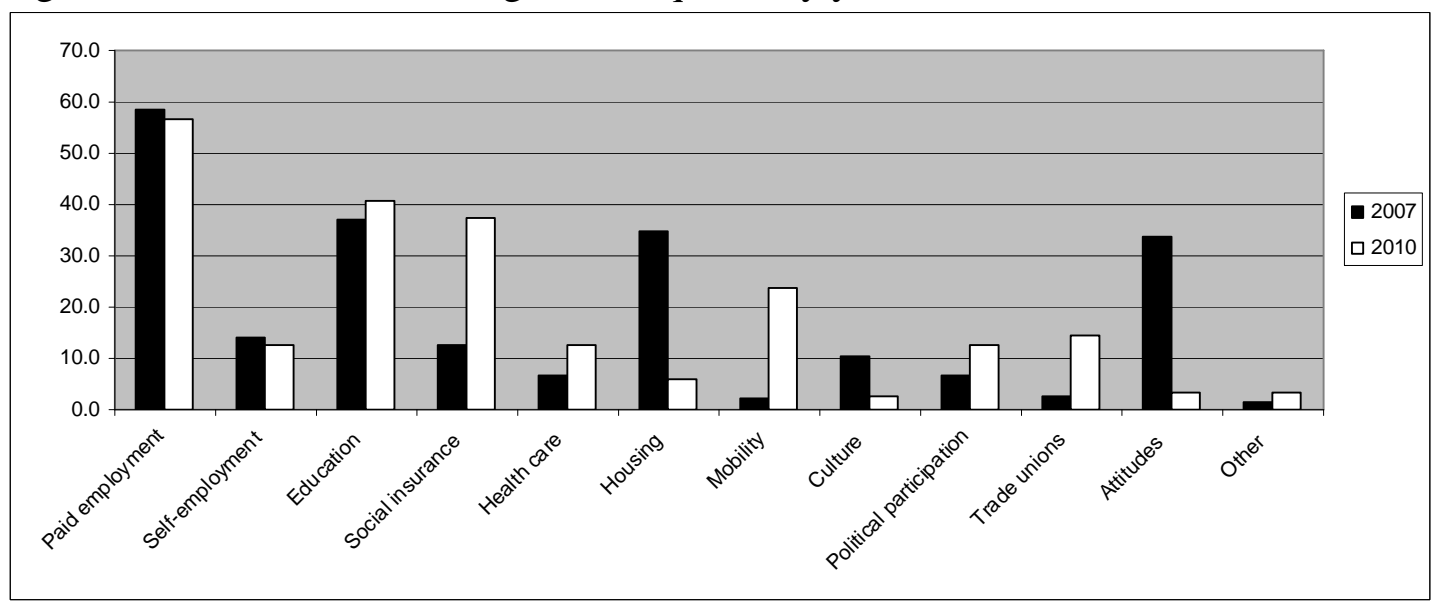

Source: IZA Expert Opinion Survey 2007 and 2010.

Notes: In percent of all respondents, including those claiming no desire for change. Answers to the question: Please indicate in which three of the following areas such changes [concerning its social and labor market integration] are most desired by members of this ethnic minority. [paid employment, including hiring, promotion, laying off, and remuneration; self-employment, including licensing; education; social insurance and benefits; health care; housing; national and international mobility; cultural, social, and religious life; political participation and representation, such as the right to vote and be elected; representation in employees' organizations, such as trade unions; attitudes of and acceptance by society; other] 
Figure 5. Areas in which changes are required by different groups of immigrants

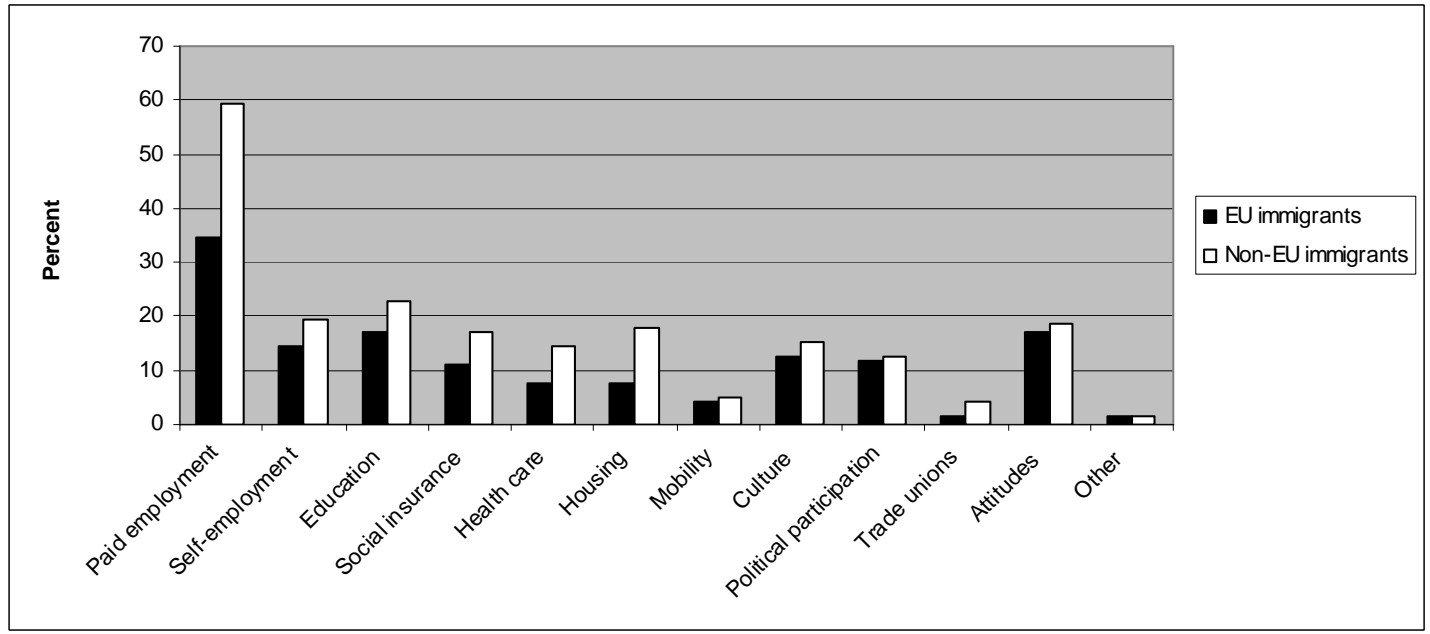

Source: IZA Expert Opinion Survey 2010.

Notes: See Figure 4. 
Figure 6. Exclusion from services

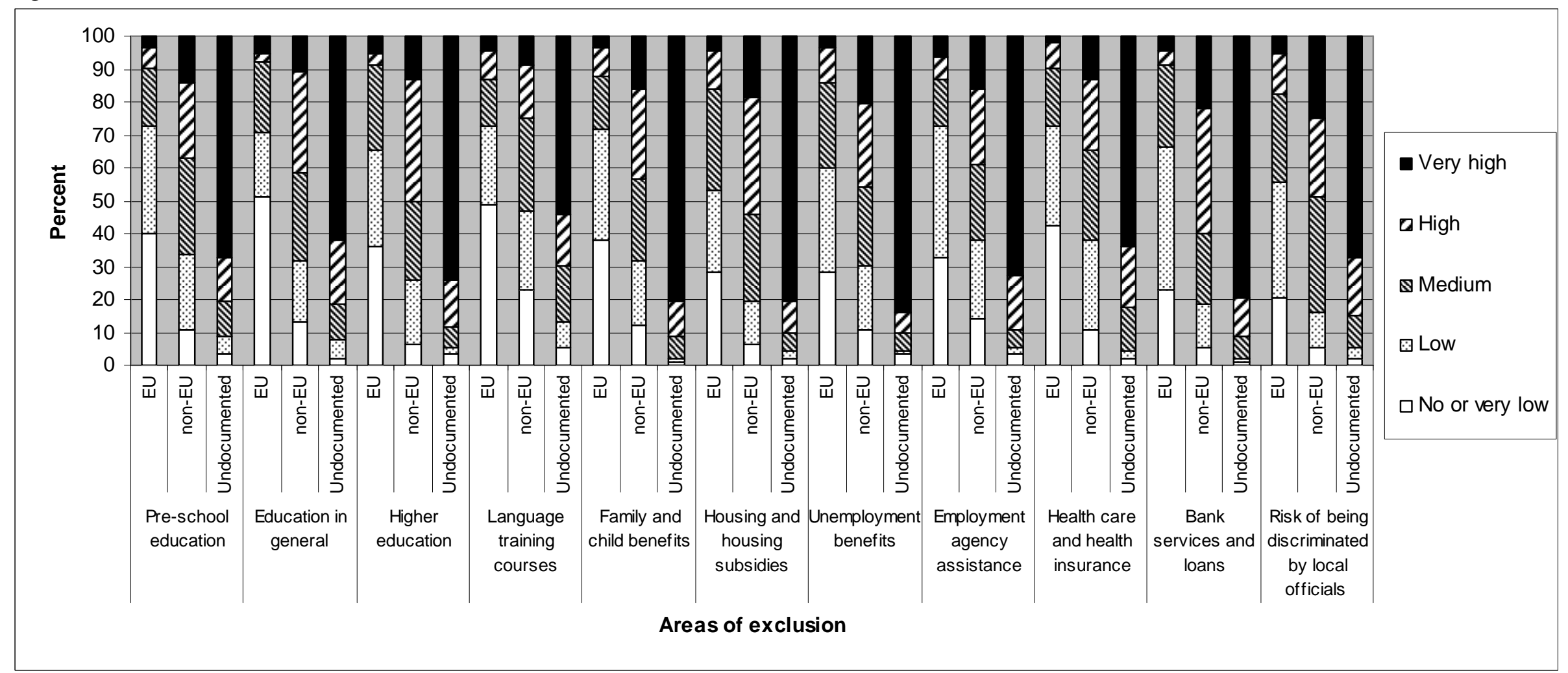

Source: IZA Expert Opinion Survey 2010.

Notes: Answers to the question: Please evaluate the risk of [immigrants of the indicated type] being excluded from, or having difficulties accessing, [indicated social service or social assistance]. 
Figure 7. The importance of active inclusion policies in the economic crisis circa 2010

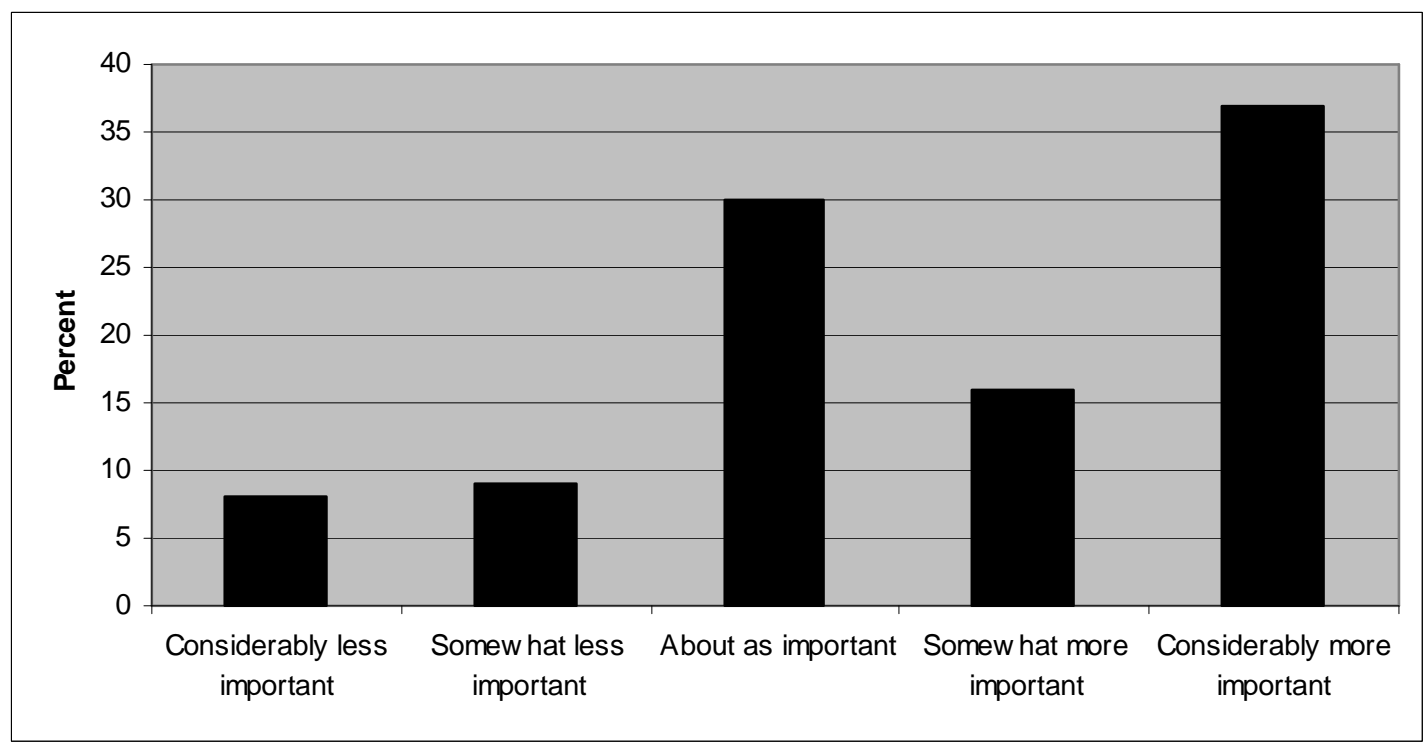

Source: IZA Expert Opinion Survey 2010

Notes: Answers to the question: How would you evaluate the effect of the current financial and economic crisis on the role of active inclusion policies targeting ethnic minorities compared to the period before the crisis?

Figure 8. Demand for enabling services at times of crisis

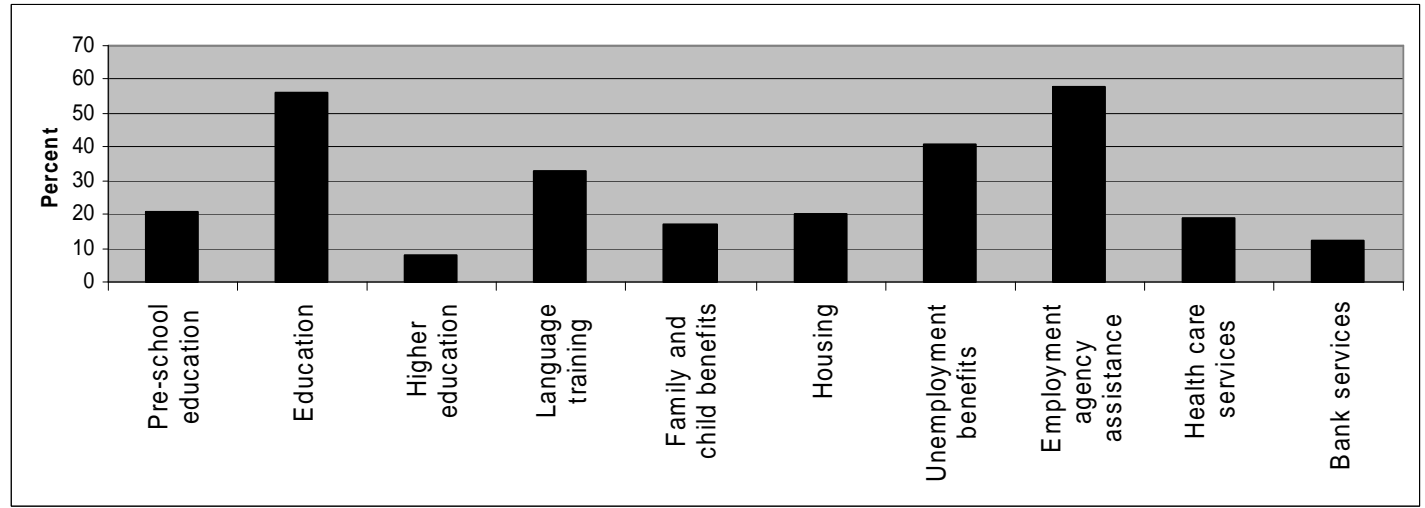

Source: IZA Expert Opinion Survey 2010

Notes: Answers to the question: Which of the following enabling services are most important in times of crisis? Please pick three. [pre-school educational institutions (kindergartens, child care facilities); education in general; higher education; language training courses; family and child benefits; housing and housing subsidies; unemployment benefits; employment agency assistance, including information about relevant job vacancies and training; health care and health insurance; bank services and credit (loans, mortgages, consumer and business credit)] 
Table 1. Determinants of expert opinions

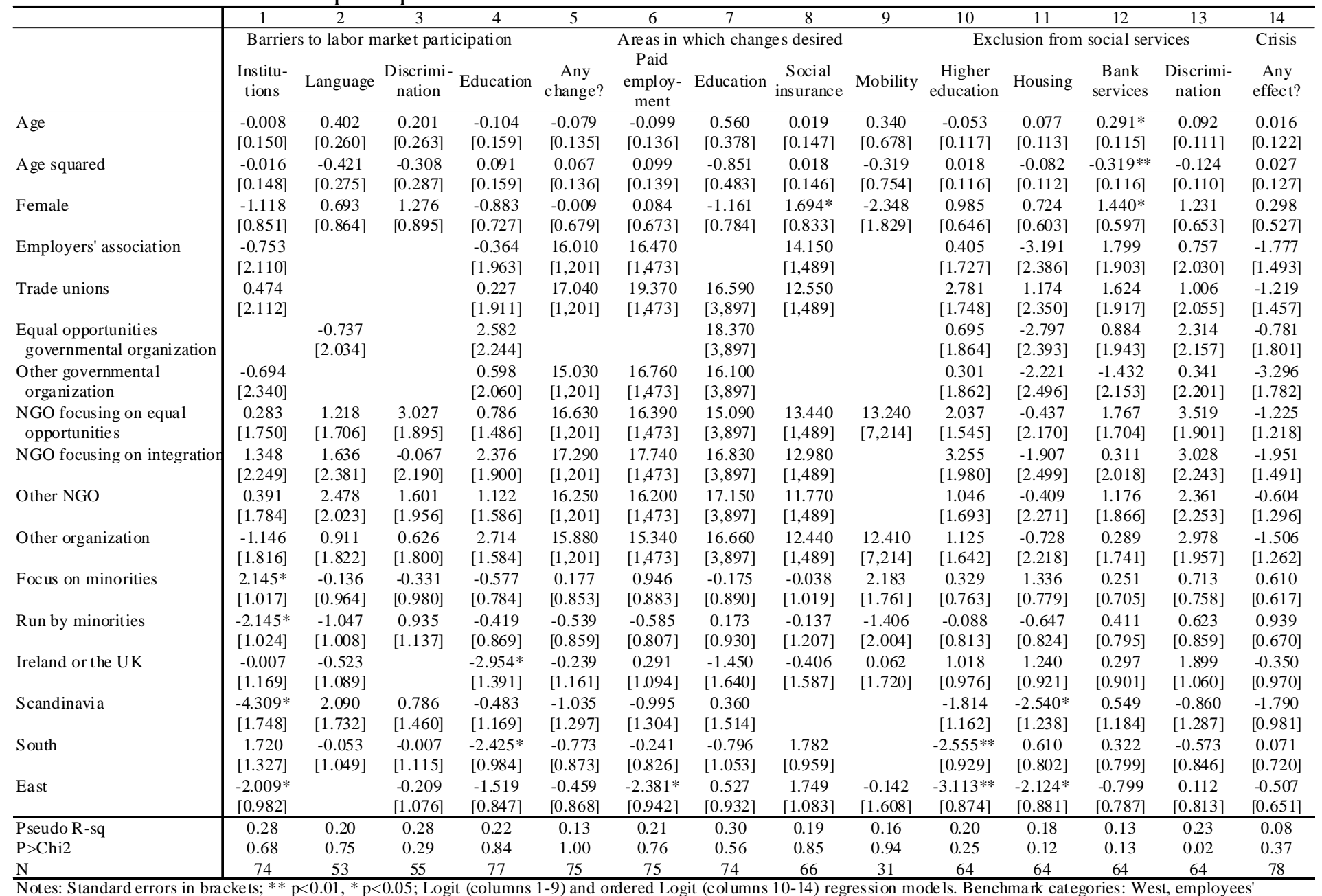

association. $\mathrm{P}>\mathrm{Chi} 2$ re ports probabilities of the Wald test of the null hypothesis that all the coefficients (excepting the regional dummies) are jointly equal to zero. 